\title{
Pemanfaatan Jagung Manis Dan Kulit Buah Naga Untuk Olahan Mie Kering Kaya Nutrisi
}

\section{Utilization Of Sweet Corn And Dragon Fruit's Skin Dry Noodle Is Rich In Nutrients}

\author{
Analianasari dan Muhammad Zaini ${ }^{1}$ \\ ${ }^{1}$ Program Studi Agribisnis Jurusan Ekonomi dan bisnis, Politeknik Negeri Lampung \\ Jl. Soekarno Hatta No 10 Rajabasa Bandar Lampung \\ E-mail: lianasaridd@gmail.com
}

\begin{abstract}
The research was aimmed at studying (1) Determine the percentage of wheat flour, sweet corn and skin dragon fruit right in the manufacture of dry noodles that can be accepted by consumers, and (2) Determine the influence of addition of sweet corn and rind of a dragon on the content of moisture, ash, protein, and preferences of consumers towards the parameters of color, flavor, elasticity, and sensory overall. The method used in this study is a factorial experimental design with two factors, namely the substitution treatment of sweet corn pasta and red dragon fruit skin extracts of the flour. Substitution of sweet corn used is 10\%, 20\% and 30\%. Medium addition of dragon fruit peel extract of 5\%,10\% and 15\%. Each experiment carried repeat 3 times, so it will be acquired unit (unit) trial were 9 units trial. The data obtained were tested with the test Barlett diversity and additional data with Tuckey test. Furthermore, to see the value of the middle test treatment Significant Difference (LSD) at 5\% level. The resulting dried noodles then analyzed the water content, ash protein, the overall sensory test. Results from the study if seen from the test sensory preferences overall, generally panelists prefer the treatment of sweet corn and dragon fruit with a concentration of 20\%, 15\% better than the taste, color and elasticity of noodles, while from the nutritional content of dried noodles sweet corn and dragon fruit SNI is in conformity with dry noodles.
\end{abstract}

Keywords: Sweet corn, dragon fruit peel, dried noodles

Diterima: 04 Februari 2016, disetujui 24 April 2016

\section{PENDAHULUAN}

Produk olahan makanan dewasa ini sangat bervariatif baik dari cita rasa maupun penampilannya. Namun, perkembangan aneka olahan makanan ringan saat ini memberikan dampak tersendiri bagi kesehatan konsumen, karena penggunaan bahan tambahan pangan yang melebihi takaran maksimum yang diizinkan penggunannya dalam olahan makanan.

Kecendrungan mengkonsumsi olahan makanan yang siap saji akibat aktivitas masyarakat yang padat menjadikan mie sebagai olahan pangan pengganti nasi. Hal ini tentu akan membantu program pemerintah one day no rice yaitu mengurangi konsumsi nasi atau beras sebanyak 1,5 persen pertahun. Program one day no rice membuka kesempatan bahan pangan lain untuk dikembangkan menjadi makanan yang sehat dan bernutrisi. Mie merupakan produk pangan yang disukai masyarakat baik dari tekstur, rasa, kenampakan maupun praktis pada saat pengolahannya. 
Astawan (2006) Mie kering yang beredar dipasaran bahan utamanya adalah tepung terigu dimana komposisi kimianya tidak mengandung vitamin A, tetapi tepung terigu sebagai bahan baku utama membuat mie yang terbuat dari biji gandum pilihan yang berkualitas tinggi, dapat merupakan zat gizi yang menyediakan energi bagi tubuh dan juga dapat membantu memperbaiki tekstur serta menambah cita rasa dari bahan pangan. Namun, ketergantungan olahan pangan akan tepung terigu yang bahan bakunya selalu impor akan dibatasi penggunaannya oleh kebijakan yang dikeluarkan oleh Menteri Perdagangan. Menurut Jakarta Post (2014), Menteri Perdagangan akan membatasi impor tepung terigu mulai bulai Mei - Desember 2014 sebanyak 441.144 ton. Hal ini tentu saja membuka peluang bahan pangan lain sebagai pangan alternatif untuk mengganti/subtitusi tepung terigu sehingga perlu dilakukan penelitian sebagai upaya mengurangi penggunaan tepung terigu pada olahan pangan.

Salah satu pangan alternatif adalah jagung manis (Zea mays saccharata sturt) karena memiliki kandungan vitamin, mineral tinggi yang dapat melengkapi kekurangan dari tepung terigu. Menurut survey marketing PT Prabu Agro Mandiri (2013), kebutuhan benih jagung manis untuk di Propinsi Lampung sebanyak 4 ton/tahun dengan luas lahan $1.000 \mathrm{Ha}$ dengan produksi 6 ton/ha atau setiap tahunnya menghasilkan jagung manis sebanyak 6.000 ton. Ketersediaan jagung manis yang berlimpah dan berkesinambungan dapat menjadikan diversifikasi olahan pangan yang bergizi tinggi dan meningkatkan nilai tambah jagung manis.

Selain itu, jagung manis mengandung kalori, serat, vitamin dan mineral serta sebagai sumber antioksidan yang baik bagi kesehatan. Sekitar 100 gr jagung manis mengandung karbohidrat 18,70 gr, Protein 3,27 gr, lemak 1,35 gr, serat 2,0 gr, vitamin A 187 IU, Vitamin B kompleks serta mengandung antioksidan fenolik flavonoid dan asam ferulat yang dapat mencegah kanker, penuaan, dan peradangan pada manusia. Hal ini tentu saja sangat menguntungkan karena dengan subtitusi jagung manis yang kaya vitamin dan mineral dapat menutupi kekurangan dari tepung terigu.

Buah naga merupakan sumber serat, vitamin, dan mineral yang baik bagi tubuh. Serat sangat dibutuhkan untuk menurunkan kadar kolesterol. Kandungan gizi secara umum yang ditemukan dalam buah ini adalah berupa potassium, ferum, serat, kalsium dan sodium. Kandungan vitamin pada buah ini juga besar dan beragam, secara umum buah naga mengandung vitamin B1, B2 dan B3. Bukan hanya buahnya saja yang berkhasiat untuk mencegah kanker, usus, kencing manis dan berbagai penyakit, tetapi khasiat juga ditemukan pada daun dan kulit buah naga maka dari itu sangat disayangkan apabila kulit buah naga yang memiliki khasiat tidak dapat digunakan sebagai bahan tambahan dalam makanan (Wahyuni, R., 2010).

Kulit buah naga mengandung zat warna alami bettasianin cukup tinggi Penggunaan zat warna sangat diperlukan untuk menghasilkan suatu produk yang lebih bervariasi dan juga menambah nilai artistik produk. Banyaknya penggunaan zat warna sintetis pada produk makanan dapat membahayakan kesehatan. Oleh karena itu, untuk mengatasi penggunaan zat warna sintesis pada produk pangan maka pemanfaatan kulit buah naga sebagai zat warna alami pada produk pangan sangat penting untuk dilakukan. Betasianin merupakan zat warna yang berperan memberikan warna merah dan merupakan golongan betalain yang berpotensi menjadi pewarna alami untuk pangan dan dapat dijadikan alternatif pengganti pewarna sintetik yang lebih aman bagi kesehatan. Kulit buah naga (Hylocereus Polyrhizus) dapat diaplikasikan sebagai pewarna alami pangan dan sebagai bahan tambahan untuk meningkatkan nilai gizi produk.

Penelitian ini bertujuan (1) Mengetahui persentase tepung terigu, jagung manis dang kulit buah naga yang tepat dalam pembuatan mie kering yang dapat diterima konsumen dan (2) Mengetahui pengaruh penambahan jagung manis dan kulit buah naga terhadap kandungan kadar air, abu, dan protein, dan kesukaan konsumen terhadap parameter warna, rasa, elastisitas, dan keseluruhan. 


\section{METODE}

Penelitian dilakukan di Laboratorium Logistik Agribisnis sedangkan analisis kimia dan uji organoleptik di laksanakan di Laboratorium Teknologi Pangan Politeknik Negeri Lampung pada bulan Mei - Juni 2015. Penelitian ini menggunakan percobaan rancangan faktorial dengan dua faktor perlakuan yaitu substitusi pasta jagung manis dan ekstrak kulit buah naga merah pada tepung terigu. Substitusi jagung manis yang digunakan yaitu 10\%, 20\%, dan 30\%, Sedang penambahan ekstrak kulit buah naga yaitu 5\%,10\%, dan 15\%. Masing-masing percobaan dilakukan ulangan sebanyak 3 kali, sehingga akan diperoleh satuan (unit) percobaan sebanyak 9 unit percobaan. Data yang diperoleh diuji keragaman dengan uji Barlett dan penambahan data dengan uji Tuckey. Selanjutnya untuk melihat nilai tengah perlakuan dilakukan uji Beda Nyata Terkecil (BNT) pada taraf 5\%. Mie kering yang dihasilkan kemudian dianalisa kandungan air, abu protein, dan uji sensori.

\section{HASIL DAN PEMBAHASAN}

\section{(1) Kadar Kimia}

Analisis kimia mie kering jagung manis dan kulit buah naga meliputi kadar air, kadar abu dan kadar protein.

\section{Kadar air mie kering}

Air merupakan komponen yang sangat penting dalam bahan makanan karena air dapat mempengaruhi penerimaan, kenampakan, kesegaran, tekstur serta cita rasa makanan (Winarno, 2004). Hasil uji kimia kadar air mie kering jagung manis dan kulit buah naga berdasarkan berbagai perlakuan disajikan pada Tabel 1.

Tabel 1. Kadar air Mie kering

\begin{tabular}{|c|c|c|c|}
\hline \multicolumn{4}{|c|}{ Jagung Manis } \\
\hline Kulit Buah Naga & $10 \%(\mathrm{~J} 1)$ & $20 \%(\mathrm{~J} 2)$ & $30 \%(\mathrm{~J} 3)$ \\
\hline $5 \%(\mathrm{~N} 1)$ & $9,167 \mathrm{ab}$ & $9,326 \mathrm{ab}$ & $9,025 \mathrm{a}$ \\
\hline $10 \%(\mathrm{~N} 2)$ & $9,498 \mathrm{ab}$ & $9,482 \mathrm{ab}$ & $10,171 \mathrm{c}$ \\
\hline $15 \%(\mathrm{~N} 3)$ & $9,068 \mathrm{ab}$ & $9,536 \mathrm{~b}$ & $10,792 \mathrm{~d}$ \\
\hline
\end{tabular}

Keterangan: Notasi yang berbeda menunjukkan adanya perbedaan yang signifikan $(\alpha=0,05)$

Berdasarkan Tabel 4 terdapat kecendrungan bahwa semakin besar konsentrasi jagung manis dan kulit buah naga yang ditambahkan kadar air semakin meningkat. Kadar air terendah $(9,025)$ terdapat pada mie kering dengan perlakuan penambahan jagung manis dan buah naga $(30 \%, 5 \%)$, sedangkan kadar air yang tertinggi $(10,792)$ pada perlakuan penambahan jagung manis dan kulit buah naga $(30 \%, 15 \%)$. Peningkatan kadar air tersebut karena jagung manis dan kulit buah naga mengandung air yang cukup tinggi sehingga penambahan jagung manis dan kulit buah naga menyebabkan kadar air meningkat. Menurur Iskandar (2007) kandungan kadar air jagung manis (72,7 g) dan kandungan kadar air buah naga 90\% dari berat buah. Peningkatan kadar air juga seiring dengan dengan penelitian Suwita, dkk (2013), untuk pembuatan mie kering kadar air bahwa penambahan bayam $40 \%$ meningkatkan kadar air tertinggi mie kering sebesar 8,69\% sedangkan tanpa penambahan bayam (0\%) memiliki kadar air terendah $(8,083 \%)$.

Nilai kadar air yang tinggi pada mie kering pada perlakuan penambahan jagung manis yang tinggi (30\%) disebabkan karena kandungan gula yang berasal dari biji jagung manis. Biji jagung 
manis terdapat fraksi-fraksi gula bebas sebesar 1\% -3\% yang terdapat dalam lembaga dan endosperm berupa sukrosa, glukosa, fruktosa dan maltosa (Rukmana, tanpa tahun). Sedangkan Setianty (2011) menyatakan bahwa biji jagung manis mengandung gula pereduksi (glukosa dan fruktosa), sukrosa, polisakarida dan pati. Kadar gula pada endosperm jagung manis sebesar 5-6\% dan kadar pati 10-11\%. Gula memiliki kemampuan mengikat dan menyerap air sebanyak 1\% dari total bahan (Sudarmadji, 1984), sehingga ketika jagung manis diolah menjadi mie kering, air dalam adonan akan sulit untuk menguap karena terperangkap dalam molekul gula. Hal inilah yang menyebabkan masih ada sebagian kecil air masih berada dalam produk mie kering.

Berdasarkan hasil analisis Anova pada tingkat kepercayaan 95\% menunjukkan bahwa terdapat pengaruh yang signifikan penambahan jagung manis dan kulit buah naga merah terhadap kenaikan kadar air mie kering yang dihasilkan. Hasil uji lanjut DMRT menunjukkan bahwa kadar air mie kering pada taraf perlakuan jagung manis dan buah naga $(20 \%, 15 \%),(30 \%, 5 \%),(30 \%, 10 \%)$, dan $(30 \%, 15 \%)$ secara statistik berbeda signifikan sedangkan kadar air mie kering taraf perlakuan $(10 \%$, $5 \%),(10 \%, 10 \%),(10 \%, 15 \%),(20 \%, 5 \%)$, dan $(20 \%, 10 \%)$ secara statistik tidak ada perbedaan yang signifikan. Menurut Winarno (2004) menjelaskan bahwa kadar air yang terkandung dalam bahan pangan mempengaruhi daya tahan terhadap serangan mikroba. Semakin sedikit kandungan kadar air pada bahan pangan dapat memperpanjang umur simpan dibandingkan bahan pangan yang mengandung kadar air tinggi. Menurut SNI 01-2974-1996, syarat kadar air mie kering berkisar antara $8-10 \%$. Hasil kadar air mie kering dalam penelitian adalah berkisar antara 9,025-10,792\% sehingga telah memenuhi standar yang telah ditentukan.

\section{Kadar abu mie kering}

Kadar abu terdiri dari unsur mineral. Dalam proses pembakaran, bahan-bahan organik terbakar tetapi zat anorganik tidak oleh karena itulah disebut abu (Winarno, 2004). Kadar abu berkaitan dengan mineral yang dikandung oleh suatu bahan. Hasil uji kimia kadar abu mie kering jagung manis dan kulit buah naga berdasarkan berbagai perlakuan disajikan pada Tabel 2.

Tabel 2. Kadar abu mie kering

\begin{tabular}{cccc}
\hline Jagung Manis & & & \\
\hline Kulit Buah Naga & $10 \%$ & $20 \%$ & $30 \%$ \\
\hline $5 \%$ & $1,031 \mathrm{ab}$ & $1,003 \mathrm{ab}$ & $1,061 \mathrm{ab}$ \\
\hline $10 \%$ & $1,089 \mathrm{ab}$ & $0,961 \mathrm{a}$ & $1,095 \mathrm{abc}$ \\
\hline $15 \%$ & $1,104 \mathrm{abc}$ & $1,130 \mathrm{bc}$ & $1,257 \mathrm{c}$ \\
\hline
\end{tabular}

Keterangan: Notasi yang berbeda menunjukkan adanya perbedaan yang signifikan $(\alpha=0,05)$

Berdasarkan Tabel 2, interaksi antara sampel satu dengan yang lain mempunyai nilai yang tidak signifikan. Kadar abu sampel mie kering berkisar antara 0,961 - 1,257 \%. Semakin banyak jagung manis dan kulit buah naga yang ditambahkan pada pembuatan mie kering semakin tinggi kadar abunya. Hal ini disebabkan jagung manis terkandung berbagai jenis mineral. Menurut Iskandar (2007) jagung manis tiap $100 \mathrm{~g}$ bahan mengandung kalsium $(3 \mathrm{mg}$ ), fosfor $(111 \mathrm{mg})$ dan besi $0,7 \mathrm{mg})$. Sedangkan kulit buah naga menurut penelitian Daniel dkk (2014) tepung kulit buah naga merah mengandung kalsium $(1,82 \%)$ dan sedikit mengandung fosfor $\left(2,08 \times 10^{-3} \%\right)$.

Berdasarkan hasil analisis Anova pada tingkat kepercayaan 95\% menunjukkan bahwa tidak terdapat pengaruh yang signifikan penambahan jagung manis dan kulit buah naga merah terhadap kenaikan kadar abu mie kering yang dihasilkan, dimana hal ini sudah sesuai standar SNI 01-29741992, yaitu kadar abu maksimum pada mie kering yaitu 3. Jika dibandingkan dengan persyaratan 
kadar abu maksimum pada SNI, kadar abu mie kering jagung manis dan buah naga dibawah persyaratan kadar abu SNI, sehingga dapat dikatakan bahwa berdasarkan kadar abunya, mie kering yang dihasilkan telah memenuhi persyaratan mutu mie kering.

\section{Kadar Protein}

Kandungan protein yang terdapat dalam bahan pangan merupakan suatu kelebihan tersendiri bagi orang yang mengkonsumsinya. Protein merupakan zat yang berfungsi sebagai bahan bakar dalam tubuh juga berfungsi sebagai zat pembangun dan pengatur (Winarno, 2004). Hasil uji kimia kadar protein mie kering jagung manis dan kulit buah naga berdasarkan berbagai perlakuan disajikan pada Tabel 3.

Berdasarkan Tabel 3 interaksi antara sampel satu dengan yang lain mempunyai nilai yang signifikan. Kadar protein sampel mie kering berkisar antara 8,731 - 12,832 \%. Semakin banyak penambahan jagung manis dan kulit buah naga, maka kadar protein semakin berkurang.

Tabel 3. Kadar protein mie kering

\begin{tabular}{|c|c|c|c|}
\hline \multirow{2}{*}{ Kulit Buah Naga } & \multicolumn{3}{|c|}{ Jagung Manis } \\
\hline & $10 \%$ & $20 \%$ & $30 \%$ \\
\hline $5 \%$ & $12,832 \mathrm{~g}$ & $8,731 \mathrm{a}$ & $9,756 \mathrm{~b}$ \\
\hline $10 \%$ & $11,089 \mathrm{~d}$ & $11,981 \mathrm{f}$ & $11,289 \mathrm{e}$ \\
\hline $15 \%$ & $11,042 \mathrm{~d}$ & $10,957 \mathrm{c}$ & $10,951 \mathrm{c}$ \\
\hline
\end{tabular}

Keterangan: Notasi yang berbeda menunjukkan adanya perbedaan yang signifikan $(\alpha=0,05)$

Hal ini dikarenakan jagung manis dan kulit buah naga sedikit mengandung protein, penambahan jagung manis dan kulit buah naga dengan jumlah yang banyak pada adonan mie menyebabkan konsentrasi air pada adonan semakin tinggi, sehingga protein yang larut dalam air banyak yang hilang. Selain itu faktor dari proses perebusan dengan suhu $100^{\circ} \mathrm{C}$ dan proses pengeringan dapat menyebabkan berkurangnya kadar protein mie kering.

\section{(2) Uji Organoleptik}

\section{Organoleptik Rasa}

Rasa merupakan faktor penting dalam menentukan daya terima produk. Warna, Tekstur dan aroma yang baik bila produk tidak memiliki rasa yang enak maka produk tidak dapat diterima oleh seseorang (Winarno, 2004). Penerimaan panelis terhadap rasa berdasarkan berbagai perlakuan disajikan pada Gambar 1.

Rasa mie kering meningkat sejalan dengan peningkatan jagung manis dan kulit buah naga tetapi rasa menurun pada pelakuan penambahan jagung manis dengan konsentrasi yang lebih tinggi (30\%). Hal ini diduga disebabkan oleh aroma khas jagung manis yang terdapat pada jagung manis yang menyebabkan penurunan cita rasa pada mie. Sedangkan penambahan kulit buah naga tidak memberikan pengaruh yang signifikan terhadap rasa, karena kulit buah naga tidak memiliki rasa yang khas.

Namun secara umum rasa mie dengan penambahan jagung masih dan kulit buah naga dapat diterima oleh panelis dengan nilai yang diberikan oleh panelis agak suka hingga suka (3-4). Oleh karena itu, jagung manis dapat digunakan sebagai alternatif untuk pembuatan mie kering dalam penambahan tepung terigu dengan tidak mempengaruhi rasa dari mie itu sendiri, sehingga konsumen 
bisa tetap menikmati mie dengan rasa yang khas dan produsen bisa menghemat penggunaan tepung terigu dengan adanya penambahan tersebut.

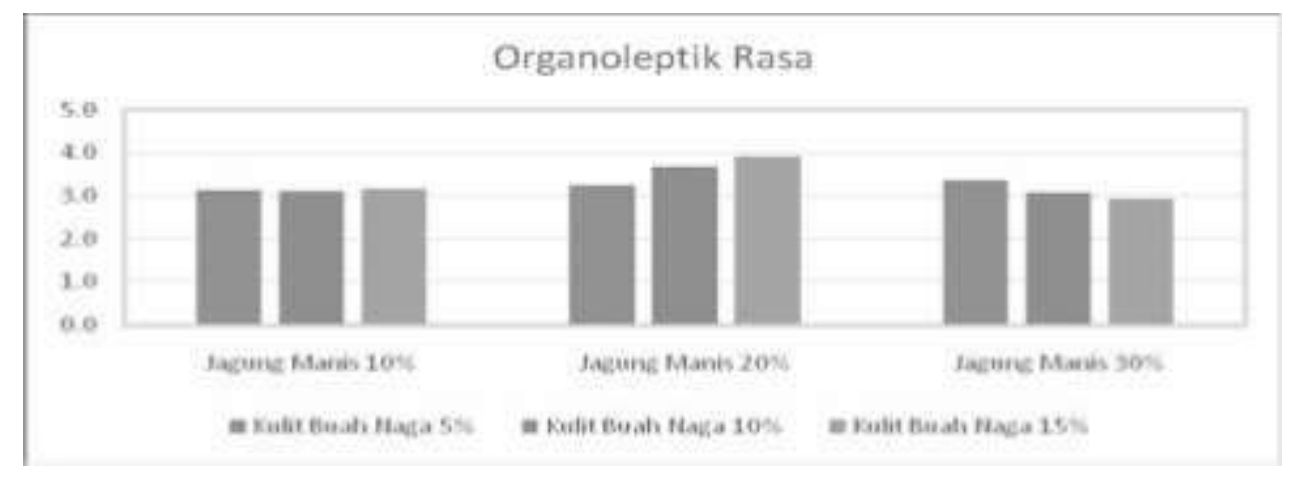

Gambar 1. Rerata kesukaan panelis terhadap rasa mie kering jagung manis dan kulit buah naga

\section{Organoleptik Warna}

Produk makanan yang memiliki warna menarik menjadikan faktor penentu bagi konsumen untuk mengkonsumsi makanan tersebut. Kulit buah naga merupakan limbah yang belum termanfaatkan. Penelitian Li Chen Wu (2005) dalam Wahyuni, R (2011) kulit buah naga kaya polyphenol dan sumber antioksidan yang baik. Bahkan menurut studi yang dilakukannya terhadap total phenolic konten, aktivitas antioksidan dan kegiatan antiproliferative, kulit buah naga merah adalah lebih kuat inhibitor pertumbuhan sel-sel kanker daripada dagingnya dan tidak mengandung toksik. Lebih lanjut Saati (2009) dalam Wahyuni, R., (2011) dalam penelitiannya, ekstrak kulit buah naga super merah (Hylocereus costaricensis) dengan pelarut air mengandung $1,1 \mathrm{mg} / 100 \mathrm{ml}$ antosianin Penambahan ekstrak kulit buah naga pada pembuatan mie kering ini diharapkan bisa menambah kesukaan konsumen terhadap mie yang dihasilkan. Suatu bahan yang dinilai bergizi, enak, dan teksturnya sangat baik tidak akan dimakan apabila memiliki warna yang tidak sedap dipandang atau memberi kesan telah menyimpang dari warna yang seharusnya (Anam dan Handajani, 2010). Lebih lanjut Winarno (2002) menyatakan bahwa penerimaan warna suatu bahan berbeda-beda tergantung faktor alam, geografis, dan aspek sosial masyarakat penerima. Penerimaan panelis terhadap warna berdasarkan berbagai perlakuan disajikan pada Gambar 2.

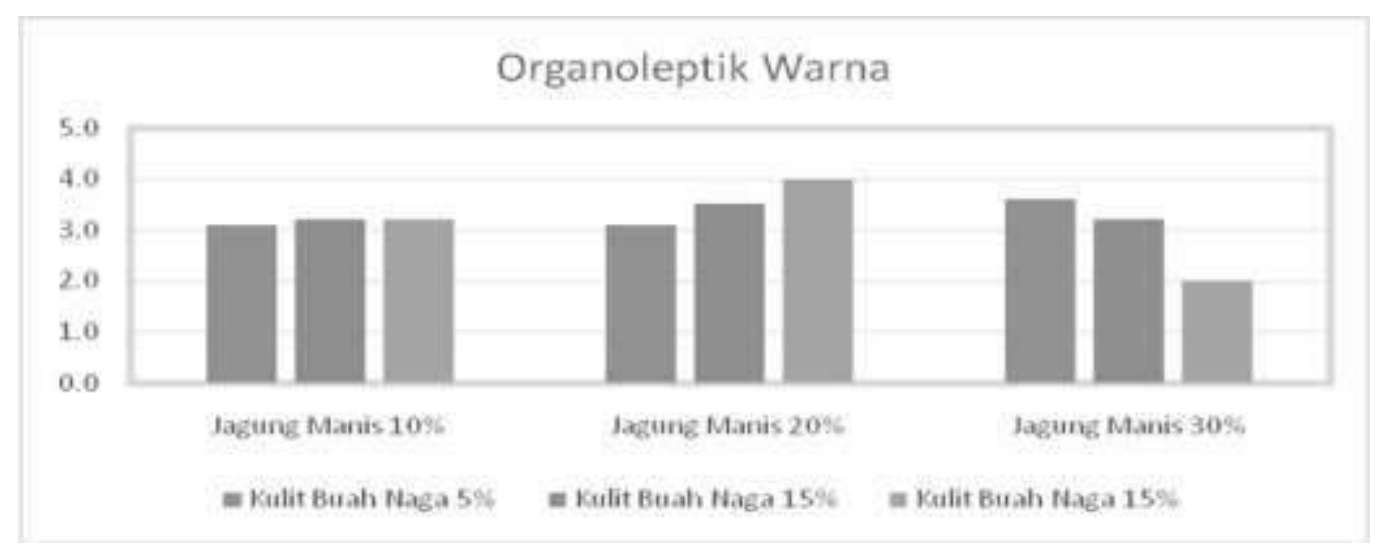

Gambar 2. Rerata kesukaan panelis terhadap warna mie kering jagung manis dan kulit buah naga

Hal ini diduga penambahan ekstrak jagung manis mengikat antosianin dari esktrak kulit buah naga menyebabkan warna mie kuning keputihan. Selain itu, hilangnya warna pada mie kering diduga 
akibat proses pemanasan pada saat pengukusan sebelum mie dikeringkan. Hendry dan Houghton, 1996 dalam Hayati, dkk (2012), suhu penyimpanan maupun suhu proses pengolahan mempengaruhi degradasi antosianin. Jadi pada suhu pengolahan yang tinggi dan selama penyimpanan akan menyebabkan degradasi antosianin. Hasil uji sensoris pada atribut warna, secara umum panelis memberikan penilaian warna mie kering pada kisaran tidak suka sampai suka $(2,00-4,00)$. Hal ini dikarenakan adanya warna merah muda pada sampel mie kering sehingga panelis lebih menyukai dibandingkan mie kering dengan warna kuning keputihan.

\section{Organoleptik Elastisitas}

Elastisitas mie kering dari penilaian panelis dapat dilihat pada Gambar 3. Berdasarkan uji sensoris mie kering terhadap atribut elastisitas, secara umum panelis memberikan penilaian tidak suka hingga netral $(2,58-3,89)$.

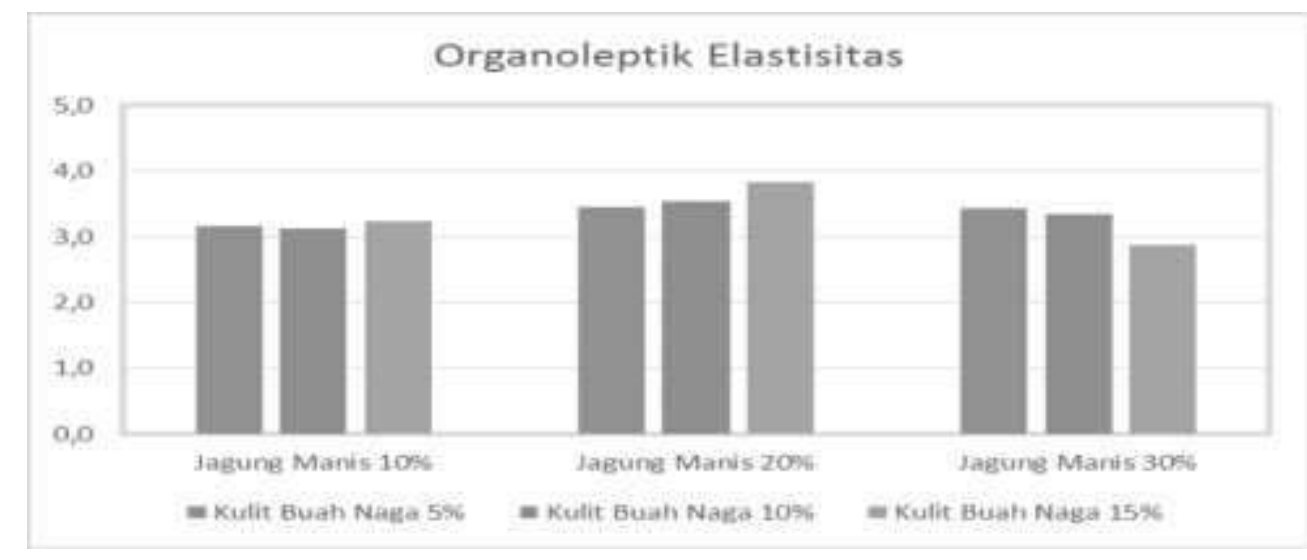

Gambar 3. Rerata kesukaan panelis terhadap elastisitas mie kering jagung manis dan kulit buah naga

Elastisitas mie kering yang dihasilkan pada setiap perlakuan panelis memberikan nilai kesukaan netral. Hal ini disebabkan karena adanya penambahan jagung manis dan kulit buah naga pada adonan mie kering sehingga kadar air semakin meningkat. Kadar air merupakan salah satu faktor yang mempengaruhi tekstur adonan dalam pembuatan mie (Winarno, 2002). Ketersediaan air memungkinkan terbentuknya gluten. U.S Wheat Associates, (1981) gluten dapat terbentuk apabila protein tepung dicairkan dengan air. Air mempunyai fungsi mengembangkan serat-serat gluten dalam adonan karena gluten menyerap air. Pada proses pengolahan mie terjadi proses peremasan pada adonan yang menyebabkan serat-serat gluten tertarik sehingga adonan menjadi lunak, kenyal dan elastis. Air di dalam adonan akan menyebabkan serat-serat gluten mengembang, karena gluten menyerap air. Peremasan terhadap adonan, serat-serat gluten ditarik sehingga terbentuk adonan yang lunak, kenyal serta elastis. Sifat elastis gluten pada adonan mie menyebabkan mie yang dihasilkan tidak mudah putus pada proses pencetakan dan pemasakan. Jika penambahan jagung manis lebih banyak (30\%) maka mengakibatkan mie yang dihasilkan mudah putus dan menurunkan penilaian panelis terhadap elastisitas.

\section{Organoleptik Kesukaan Keseluruhan}

Penilaian kesukaan secara keseluruhan terhadap parameter mie kering yaitu rasa, warna, dan elastisitas dapat dijadikan petunjuk perlakuan mana yang disukai oleh panelis. Berdasarkan uji 
sensoris mie kering terhadap atribut kesukaan keseluruhan, secara umum panelis memberikan penilaian netral hingga suka $(3,00-4,00)$ (Gambar 4).

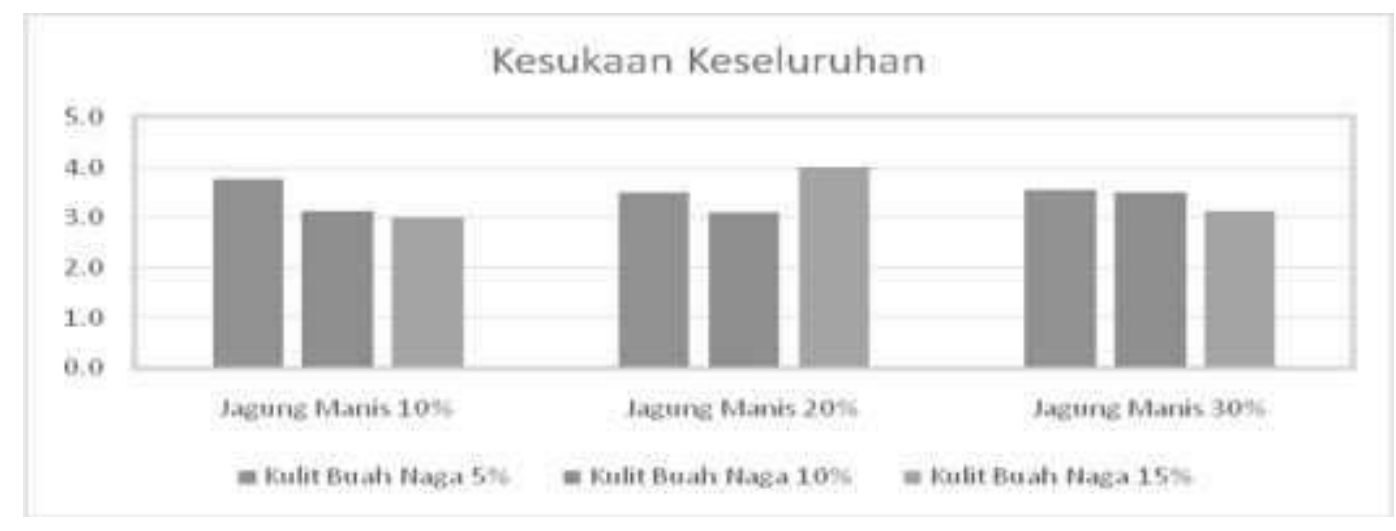

Gambar 4. Rerata kesukaan panelis terhadap kesukaan keseluruhan mie kering jagung manis dan kulit buah naga

Kesukaan secara keseluruhan panelis pada perlakuan jagung manis dan buah naga dengan konsentrasi $(20 \%, 15 \%)$. Faktor yang disukai panelis pada mie kering diduga faktor warna yang lebih cerah dan menarik perhatian panelis dari perlakuan lain.

\section{Kesimpulan}

1. Uji sensoris kesukaan keseluruhan, secara umum panelis lebih suka pada perlakuan jagung manis dan buah naga dengan konsentrasi 20\%,15\% baik dari rasa, warna dan elastisitas mie.

2. Kandungan gizi mie kering jagung manis dan buah naga sudah sesuai dengan SNI mie kering.

\section{Saran}

Untuk penelitian selanjutnya dalam pemakaian kulit buah naga sebagai pewarna alami yang menghasilkan warna ungu pada produk pangan penulis menyarankan untuk melakukan pengujian proses pengolahan yang tepat sehingga dapat mempertahankan antosianin yang dikandung kulit buah naga.

\section{DAFTAR PUSTAKA}

Astawan, M., 2006. Membuat Mie dan Bihun. Penebar Swadaya, Jakarta.

AOAC. 1995. Official Methods of Analysis, 16th ed. AOAC International, Gaithersbug, Maryland.

Choiroel Anam dan Sri Handajani., 2010. Mi Kering Waluh (Cucurbita Moschata) Dengan Antioksidan Dan Pewarna Alami. Jurnal Caraka Tani XXV No.1 Maret 2010.

Daniel, R.S., Osfar S dan Irfan H.D. 20014. Kajian Kandungan Zat Makanan dan Pigmen Antosianin 3 Jenis Kulit Buah Naga (Hyloceneus sp) sebagai Bahan Pakan Ternak. http://fapet.ub.ac.id/wpcontent/uploads /2014/06/. Diakses 20 September 2015. 
Hayati, E.K., Budi U.S dan Hermawan, R. 2012. Konsentrasi Total Senyawa Antosianin Ekstrak Kelopak Bunga Rosella (Hibiscus Sabdariffa L): Pengaruh Temperatur dan pH. Jurnal Kimia 6 (2) ISSN 1907-9850. Hal 138-147.

I Komang Suwita, Maryam Razak, Rizga Andari Putri. 2013. Pemanfaatan Bayam Merah (Blitum Rubrum) untuk Meningkatkan Kadar Zat Besi dan Serat pada Mie Kering. http://jurnal.yudharta.ac.id/ wp-content/ uploads/2013/04/2I diakses tanggal 20 September 2015.

Iskandar, D., 2007. Pengaruh Dosis Pupuk N,P terhadap Pertumbuhan dan Produksi Tanaman Jagung Manis di Lahan Kering. http://www.iptek.net.id diakses 20 September 2015.

Koran Jakarta. 2014. Perlu Kebijakan Tegas Hentikan Impor Gandum. http://www.koran-jakarta.com. diakses Tanggal 20 April 2014.

PT Prabu Agro Mandiri, 2014. Laporan area Tahunan Tim Marketing Lampung.

Rekna Wahyuni, 2011. Pemanfaatan Kulit Buah Naga Supermerah (Hylicereus Costaricensis) Sebagai Sumber Antioksidan Dan Pewarna Alami Pada Pembuatan Jelly. Jurnal Teknologi Pangan Vol.2 No.1 November 2011.

Setianty, P.A. 2011. Pembuatan Minuman Probiotik Jagung Manis http://www.scribd.com/doc/ di akses pada tanggal 20 September 2015.

SNI 01-2974-1996. Mie Kering. Badan Standarisasi Nasional. Jakarta.

Sudarmadji, S.B. Haryono dan Suhardi, 1984. Prosedur Analisa Untuk Bahan Makanan dan Pertanian. Yogyakarta. Liberty.

U.S Wheat Associaties. 1981. Pedoman Pembuatan Roti dan Kue. Penerbit Djambatan. Jakarta.

Winarno, F.G. 2004. Kimia Pangan dan Gizi. Gramedia. Pustaka Umum. Jakarta. 